\title{
The impact of HIVIAIDS on human development in African countries
}

\author{
Abdesslam Boutayeb
}

Address: Faculty of Sciences, University Mohamed Ier, Boulevard Mohamed VI BP: 717, Oujda-Morocco

Email: Abdesslam Boutayeb - x.boutayeb@menara.ma

Published: 18 November 2009

BMC Public Health 2009, 9(SuppI I):S3 doi:I0.1 186/147I-2458-9-SI-S3

This article is available from: http://www.biomedcentral.com/I47I-2458/9/SI/S3

(C) 2009 Boutayeb; licensee BioMed Central Ltd.

This is an open access article distributed under the terms of the Creative Commons Attribution License (http://creativecommons.org/licenses/by/2.0), which permits unrestricted use, distribution, and reproduction in any medium, provided the original work is properly cited.

\begin{abstract}
Background: In the present paper, we consider the impact of HIVIAIDS on human development in African countries, showing that, beyond health issues, this disease should and must be seen as a global development concern, affecting all components of human development. Consequently, we stress the necessity of multidisciplinary approaches that model, estimate and predict the real impact of HIVIAIDS on human development of African countries in order to optimise the strategies proposed by national countries, international institutions and their partners.

Methods: In our search strategy, we relied on secondary information, mainly through National Human Development Reports of some African countries and regular publications released by the United Nations (UN), United Nations Development Programme (UNDP), World Health Organization (WHO) and the World Bank. We restricted ourselves to reports dealing explicitly with the impact of HIVIAIDS on human development in African countries.

Results and discussion: HIVIAIDS is affecting the global human development of African countries through its devastating impact on health and demographic indicators such as life expectancy at birth, healthcare assistance, age and sex distribution, economic indicators like income, work force, and economic growth, education and knowledge acquisition and other indicators like governance, gender inequality and human rights.

Conclusion: On the basis of the national reports reviewed, it appears clearly that HIVIAIDS is no longer a crisis only for the healthcare sector, but presents a challenge to all sectors. Consequently, HIVIAIDS is a development question and should be viewed as such. The disease is impeding development by imposing a steady decline in the key indicators of human development and hence reversing the social and economic gains that African countries are striving to attain. Being at the same time a cause and consequence of poverty and underdevelopment, it constitutes a challenge to human security and human development by diminishing the chances of alleviating poverty and hunger, achieving universal primary education, promoting gender equality, reducing child and maternal mortality, and ensuring environmental sustainability.
\end{abstract}

\section{Background}

Since 1990, five main composite indices were developed by the United Nations to measure the average achieve- ments in basic human development (human development index (HDI), gender-related development index (GDI), human poverty indices (HPI-1 and HPI-2) and the 
Table I: Human Development Index 2006 [2]

\begin{tabular}{|c|c|c|}
\hline High HD & Medium HD & Low HD \\
\hline I. Norway & 64. Libya & 147. Togo \\
\hline 2. Iceland & 57. Bulgaria & . \\
\hline 3. Australia & 58. Malaysia & 165. Zambia \\
\hline 4. Ireland & . & 166. Malawi \\
\hline 5. Sweden & . & 167. Congo \\
\hline 6. Canada & 87. Tunisia & 168. Mozambique \\
\hline 7. Japan & . & 169. Burundi \\
\hline 8. United States & III. South Africa & 170. Ethiopia \\
\hline 9. Switzerland & . & 17I. Chad \\
\hline . & 125. Botswana & 172. Central African Rep \\
\hline . & 123. Morocco & 173. Guinea-Bissau \\
\hline \multirow[t]{3}{*}{. } & 124. Gabon & I74. Burkina Faso \\
\hline & 125. Namibia & I75. Mali \\
\hline & & 176. Sierra Leone \\
\hline 63. Mauritius & |46. Swaziland & 177. Niger \\
\hline
\end{tabular}

gender empowerment measure (GEM) [1]. HDI is the most used index, giving a summary measure of human development and allowing for a yearly comparison between countries around the world (Table 1) and indicating the relative ranking evolution in time of each country (Table 2) [2-4]. HDI is a three dimensional composite index obtained as a mean of three indicators weighed equally: health (life expectancy at birth), standard of living (GDP per capita) and education (literacy and enrolment).

In the present paper, we consider the impact of HIV/AIDS on human development in African countries, showing that, beyond health issues, this disease should and must be seen as a global development concern, affecting education and knowledge acquisition, income and social status, productivity and economic growth, and other direct and indirect components of human development such as gender equality and human rights. Consequently, we stress the necessity of multidisciplinary approaches that model, estimate and predict the real impact of HIV/AIDS on human development of African countries in order to optimise the strategies proposed by national countries, international institutions and their partners.

\section{Methods (search strategy)}

In our search strategy, we relied on secondary information mainly through National Human Development Reports of some African countries and regular publications released by the United Nations (UN), United Nations Development Programme (UNDP), World Health Organization (WHO) and the World Bank. For national reports, we restricted ourselves to the eight National Human Development Reports which dealt explicitly with the impact of HIV/AIDS globally on human development, or partially on its components during the last years.

\section{Results and discussion \\ Major infectious diseases}

With malnutrition as a common contributor, the five biggest infectious killers in the world are HIV/AIDS, malaria, tuberculosis, acute respiratory infections and diarrhoeal disease, responsible for nearly $80 \%$ of the total infectious disease burden and claiming about 12 million people per year (Table 3) [5]. Despite the success of vaccination programs for polio and many childhood diseases, other diseases like AIDS, tuberculosis and malaria are still out of control in the majority of African countries. Children remain at high risk. Indeed, in 2002, of the 57 million deaths reported worldwide, 10.5 million deaths were among children of less than five years of age, of which $98 \%$ were in developing countries in general and in Africa in particular [6-9]. Consequently, while life expectancy at birth reached 78 years for women in developed countries, it fell back to less than 46 years in sub-Saharan Africa [10]. In the following sections, we concentrate on HIV/AIDS and its impact on human development in Africa.

Table 2: HD rank evolution of ten African countries [2]

\begin{tabular}{llll}
\hline Country & $\begin{array}{l}\text { HD Rank 1990 } \\
\text { (130 countries) }\end{array}$ & $\begin{array}{l}\text { HD Rank 2000 } \\
\text { (174 countries) }\end{array}$ & $\begin{array}{l}\text { HD Rank 2006 } \\
\text { (I77 countries) }\end{array}$ \\
\hline South Africa & 62 & 103 & 121 \\
Botswana & 72 & 122 & 131 \\
Lesotho & 77 & 127 & 149 \\
Zimbabwe & 78 & 130 & 151 \\
Zambia & 87 & 153 & 165 \\
Kenya & 88 & 138 & 152 \\
Cameroun & 89 & 134 & 144 \\
Namibia & 96 & 115 & 125 \\
Malawi & 116 & 163 & 166 \\
Swaziland & not ranked & 112 & 146 \\
\hline
\end{tabular}


Table 3: Main causes of mortality due to infectious diseases, 200 I (in million) [5]

\begin{tabular}{ll}
\hline Disease & Deaths per year (millions) \\
\hline Respiratory infections & 3.9 \\
AIDS & 3.0 \\
Diarrhoeal diseases & 1.9 \\
Tuberculosis & 1.9 \\
Malaria & 1.1 \\
\hline
\end{tabular}

\section{HIVIAIDS: the indomitable disease}

Impact of HIVIAIDS on human development in selected African countries

During the last decades, the prevalence and incidence of HIV/AIDS have seen an exponential growth (Figure 1). African countries are the most affected by this epidemic, which is strongly affecting all components of human development, as indicated explicitly by the set of national human development reports given below.

\section{Zambia}

The 2007 Zambia Human Development Report (HDR) focuses on the sixth Millennium Development Goal (MDG), which is combating HIV/AIDS, malaria and other diseases. Under the title "Enhancing household capacity to respond to HIV and AIDS" [11], it is indicated that HIV/ AIDS is one of the major development challenges facing Zambia. According to this report, the epidemic has affected every fabric of human existence. It has become the major cause of illness and death among the young and middle-aged Zambians, who are the most productive age group. Consequently, it has deprived households and society of a critical human resource base (Table 4). Furthermore, it is reversing the social and economic gains the country is striving to attain. It has also continued to diminish the chances of alleviating poverty and hunger, achieving universal primary education, promoting gender equality, reducing child and maternal mortality, and ensuring environmental sustainability. In effect, HIV/ AIDS is among the factors limiting the achievement of the MDGs.

\section{Mozambique}

Stressing the danger of the growing prevalence of HIV/ AIDS (Table 5), the Mozambique National HDR 2007 states that the effects of HIV and AIDS are gradually hampering the capacity and the administrative and organizational power of the state [12]. The report considers that, globally, HIV/AIDS is a development question and should be viewed as such. More precisely, HIV/AIDS has unpredictable implications for economic and social sectors. Indeed, this epidemic is mainly concentrated on the active population, from 15 to 49 years of age. It thus has a disproportionate weight on the age groups who play a key

\section{Number of HIV/AIDS cases}

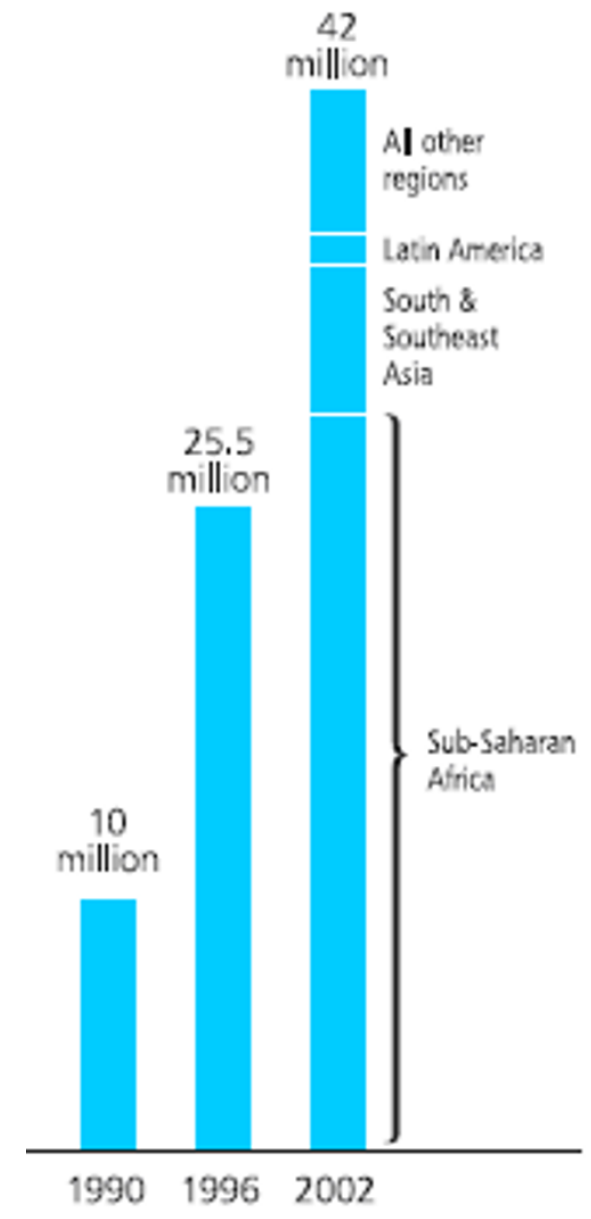

Source: Human Development Report.

\section{Figure I}

Prevalence and incidence of HIVIAIDS: An exponential growth. The number of cases affected by HIVIAIDS worldwide has increased four-fold in 121 years.

role in the development of the economy and of the country's social sectors. AIDS does not only cause sickness, incapacity or death of workers, and severe emotional and economic upheavals for families, it also increases the cost of doing business. Analyses of the sector impact of HIV and AIDS in Mozambique have advanced predictions of economic catastrophe.

\section{Kenya}

Kenya National HDR 2006 has dealt with HIV/AIDS as a challenge to human security and human development [13]. As stressed by the report, despite Kenya's recent gains in reversing the trend of HIV/AIDS incidence and prevalence, the epidemic still presents a major challenge in the 
Table 4: Zambia: life expectancy and HI with and without AIDS [II]

\begin{tabular}{lllll}
\hline Province & $\begin{array}{l}\text { Life expectancy } \\
\text { With AIDS }\end{array}$ & $\begin{array}{l}\text { Life expectancy } \\
\text { Without AIDS }\end{array}$ & $\begin{array}{l}\text { HDI } \\
\text { With AIDS }\end{array}$ & $\begin{array}{l}\text { HDI } \\
\text { Without AIDS }\end{array}$ \\
\hline Central & & & 0.458 & 0.490 \\
Capperbelt & 55.0 & 60.8 & 0.552 & 0.583 \\
Eastern & 57.6 & 63.2 & 0.367 & 0.393 \\
Luapula & 47.0 & 51.7 & 0.385 & 0.405 \\
Lusaka & 47.5 & 51.2 & 0.513 & 0.560 \\
Northern & 54.1 & 62.5 & 0.384 & 0.441 \\
Northern West & 45.5 & 55.8 & 0.453 & 0.470 \\
Southern & 55.6 & 58.7 & 0.469 & 0.512 \\
Western & 51.6 & 59.0 & 0.386 & 0.410 \\
National & 48.2 & 52.6 & 0.469 & 0.491
\end{tabular}

country, threatening sustained progress in human development. It is also underlined that HIV/AIDS remains a serious concern, as patients can remain asymptomatic for many years, masking the reality that the virus could be spreading rapidly but silently across the country (Table 6).

\section{Malawi}

Under the title "reversing HIV/AIDS in Malawi", the Malawi HDR 2005 devoted a chapter to the impact of HIV and AIDS on households welfare, orphaned children, the extended family, educational and health sectors, agricultural production, business and public service delivery. The chapter concludes that HIV and AIDS have the potential to reverse those gains made in human development in the last few years [14].

\section{Benin}

According to the Benin HDR 2005, HIV/AIDS is at the same time a cause and consequence of poverty and underdevelopment [15]. According to this report, the impact of the disease on human capacities and institutions is the most apparent. It has repercussions for the economy, health systems, education and food security at national, regional and family levels.

The prevalence of HIV/AIDS varies according to different regions of Benin. The region with the highest prevalence has the lower life expectancy index (Table 7).

Table 5: Mozambique: comparison of regional and national HIV prevalence rates $[12]$

\begin{tabular}{llll}
\hline $\begin{array}{l}\text { Year } \\
\text { Region }\end{array}$ & 200I & 2002 & 2004 \\
\hline South & 14.4 & 14.8 & 18.1 \\
Centre & 16.8 & 16.7 & 20.4 \\
North & 6.8 & 8.4 & 9.3 \\
National & 13.0 & 13.6 & 16.2 \\
\hline
\end{tabular}

\section{Zimbabwe}

Zimbabwe HDR 2003 "towards reducing vulnerability: the ultimate war for survival", states that HIV/AIDS is impeding development by imposing a steady decline in the key indicators of human development. The report concludes that it is critical that the relationship between epidemic and human development be acknowledged at all levels and that the principles of sustainable development be a major focus and priority of the country's policies and programmes [16]. Zimbabwe is among the countries the most affected by HIV/AIDS. The high prevalence of the disease has significantly affected the country's human development. Indeed, from 1995 to 2000, HDI has declined by $12 \%$, from 0.507 to 0.444 (Table 8 ).

\section{South Africa}

South Africa HDR 2003 indicates the magnitude and farreaching consequences of the HIV/AIDS pandemic, stressing that the disease is no longer a crisis only for the healthcare sector, but presents a challenge to all sectors [17]. The report discusses in detail the impact of the disease on economy and business, education and knowledge, health and social welfare. As illustrated in Figure 2, although at different levels, all South African provinces have seen a global decline in the human development index between

Table 6: Kenya: adult HIV prevalence by province and sex (\%) (2004) [13]

\begin{tabular}{lllll}
\hline Province & $\begin{array}{l}\text { HIV+ } \\
\text { (in thousands) }\end{array}$ & Male\% & Female\% & Total \\
\hline Nairobi & 159 & 7.1 & 10.9 & \\
Central & 124 & 2.3 & 8.9 & 9.0 \\
Coast & 84 & 4.8 & 6.6 & 5.6 \\
Eastern & 90 & 1.4 & 5.9 & 3.7 \\
North Eastern & 17 & 2.1 & 4.0 & 3.0 \\
Nyanza & 292 & 10.2 & 16.0 & 13.1 \\
Rift Valley & 207 & 3.5 & 6.6 & 5.0 \\
Western & 85 & 3.6 & 5.4 & 4.5 \\
National & 1057 & 4.3 & 8.3 & 6.4 \\
\hline
\end{tabular}


Table 7: Benin: HIV prevalence and life expectancy and education indices in different regions [15]

\begin{tabular}{llll}
\hline $\begin{array}{l}\text { Indicators } \\
\text { Region }\end{array}$ & HIV prevalence & Life expectancy idex & Education index \\
\hline Cuffo & & & 0.372 \\
Litteral & 3.3 & 0.547 & 0.741 \\
Oueme & 3.2 & 0.571 & 0.551 \\
Mono & 3.1 & 0.568 & 0.578 \\
Donga & 2.4 & 0.581 & 0.398 \\
Borgou & 1.2 & 0.588 & 0.348 \\
Alibori & 0.4 & 0.571 & 0.352 \\
National & 0.3 & 0.524 & 0.431
\end{tabular}

1990 and 2000. HIV/AIDS has clearly contributed significantly to this decline.

\section{Botswana}

Under the title "Towards an AIDS-Free generation" [18], the Botswana HDR 2000 considered HIV/AIDS as the Antithesis of Human Development. The report indicated that Botswana's HIV prevalence rates suggest the emergence of an enormous human development crisis. Striking at the very core of human development, HIV/AIDS shortens human life, erodes people's sense of dignity and selfesteem, causes social exclusion, and traumatises and impoverishes individuals, families and whole communities (Table 9).

\section{HIVIAIDS and human development in the most affected countries}

As indicated in Table 2, Table 10 and Figure 3, between 1990 and 2006, the most affected countries lost years of life expectancy and tens of points in the human development ranking (South Africa 62/130 to 121/177, Zimbabwe $78 / 130$ to $151 / 177$, Botswana $72 / 130$ to $131 / 177$, Kenya $88 / 130$ to $152 / 177$, Zambia $87 / 130$ to $165 / 177$, Lesotho $77 / 130$ to $149 / 177$, Namibia $96 / 130$ to $125 / 177$ and Cameroon 89/130 to 144/177).

In 1999, the Commission on Macroeconomics and Health was established to explore the relationship between health and economic development. In the report published by the commission in 2001, empirical evidence was provided on how investing in health can achieve economic development and poverty reduction. It was indicated that, by 2010, eight million lives per year could be saved by essential interventions against infectious diseases and nutritional deficiencies, resulting in economic benefits adding up to more than US $\$ 360$ per year by 2015 [21]. In order to address extreme poverty in its many dimensions, while promoting education, gender equality, environmental sustainability and global partnership for development, the United Nations (UN) Millennium Summit in 2000 [22] adopted the MDGs by fixing eight goals to be reached in 2015 (Table 11). Preventing the spread of HIV/AIDS, malaria, and other diseases is one of the goals, but it is striking to notice the impact that HIV/AIDS is having on each of the other seven goals.

However, beyond the international agreement on principles, at the 7-year juncture, most African countries, have made little (if any) headway in preventing and controlling the HIV/AIDS epidemics in particular, nor in reducing the rates of extreme poverty and making progress in the MDGs targeted for 2015 in general [23,24]. Meanwhile, it is sad to notice that in 1999, the governments of subSaharan Africa dedicated US $\$ 7$ billion to military spending, whereas diverting just $10 \%$ of this would have raised US $\$ 700$ million, more than enough to support the HIV/ AIDS vaccine research program [25].

\section{Sectorial impact of HIVIAIDS}

Impact on health indicators

HIV/AIDS is directly affecting heath and demographic indicators such as mortality rates, life expectancy, and sex and age distributions. By 2000-2005, Zimbabwe, Botswana, Swaziland and Lesotho have lost respectively 35, 28,28 and 24 years of life expectancy [16,18-20]. More generally, it is estimated that, in the seven most affected

Table 8: Zimbabwe: overall, HDI has declined by I2\%, from 0.507 to 0.444 between 1995 and 2000 [16]

\begin{tabular}{|c|c|c|c|c|}
\hline $\begin{array}{l}\text { Indicator } \\
\text { Year }\end{array}$ & $\begin{array}{l}\text { Life expectancy } \\
\text { (Life expectancy index) }\end{array}$ & $\begin{array}{l}\text { Adult literacy } \\
\text { (Adult literacy index) }\end{array}$ & $\begin{array}{l}\text { Income } \\
\text { (Index) }\end{array}$ & HDI \\
\hline 1995 & $\begin{array}{l}51.8 \\
(0.45)\end{array}$ & $\begin{array}{l}86 \\
(0.86)\end{array}$ & $\begin{array}{l}2162 \\
(0.382)\end{array}$ & 0.507 \\
\hline 2000 & $\begin{array}{l}38.2 \\
(0.22)\end{array}$ & $\begin{array}{l}88.1 \\
(0.88)\end{array}$ & $\begin{array}{l}948 \\
(0.375)\end{array}$ & 0.444 \\
\hline
\end{tabular}




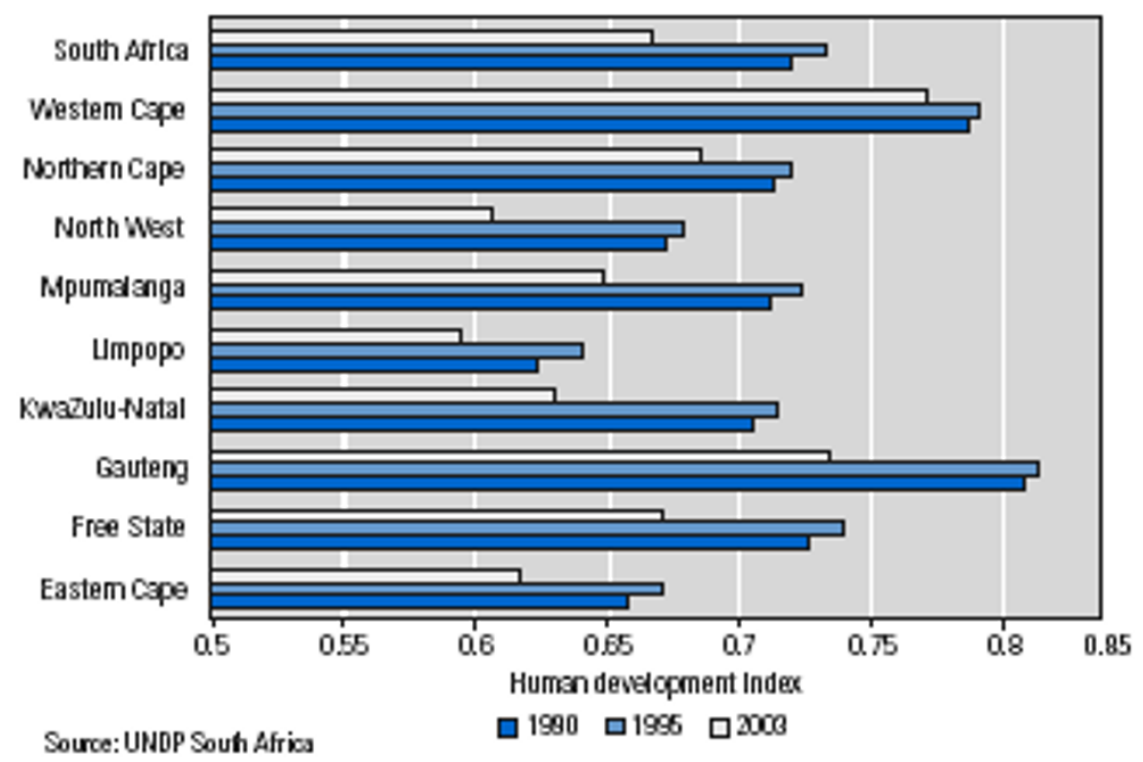

Figure 2

South Africa: Human development index (HDI) by province (1990-2003) [I7]. The Human Development Index has decreased between 1990 and 2003 in all regions of South Africa.

countries in Africa, life expectancy declined by 12.1 years by $1995-2000$ and is expected to decline by 29.4 years by 2010-2015. Similarly, the number of deaths, infant mortality rates and child mortality rates were estimated at 2 , 10.2 and 28.6 respectively for the first period and expected to reach $6,13.9$ and 43.3 respectively by 2010 2015 [19]. Globally, in 1995-2000, 38 African countries had a mean life expectancy of 47 years, representing 5.7 years of loss attributable to AIDS.

The burden of the disease is not felt only at individual level; it affects households, communities and the whole nation (hospitalisation, healthcare, orphanhood) $[12,15,17]$. More than half of all hospital beds in sub-

Table 9: The most affected African countries according to HIV prevalence in 2001 [19,20]

\begin{tabular}{|c|c|c|}
\hline $20 \%$ or more & $10 \%$ to $20 \%$ & $5 \%$ to $10 \%$ \\
\hline Botswana $36.5 \%$ & Malawi $16.1 \%$ & Côte d'Ivoire $9.6 \%$ \\
\hline Zimbabwe $33.9 \%$ & Kenya $15.0 \%$ & Rwanda 9.1\% \\
\hline Swaziland 33.7\% & Centr Afric Rep $12.9 \%$ & Burundi $8.3 \%$ \\
\hline Lesotho $30.1 \%$ & Mozambique $12.8 \%$ & Tanzania $7.8 \%$ \\
\hline Namibia $22.2 \%$ & Cameroon $11.8 \%$ & Djibouti $7.1 \%$ \\
\hline Zambia $21.6 \%$ & & Congo $7.1 \%$ \\
\hline \multirow[t]{7}{*}{ South Africa $21.3 \%$} & & Sierra Leone $6.7 \%$ \\
\hline & & Liberia $6.5 \%$ \\
\hline & & Ethiopia $6.5 \%$ \\
\hline & & Burkina Faso $6.4 \%$ \\
\hline & & Togo $6.0 \%$ \\
\hline & & Nigeria $5.8 \%$ \\
\hline & & Angola 5.5\% \\
\hline
\end{tabular}

Saharan Africa are occupied by people with HIV/AIDS and related diseases. Some of the most affected countries have lost more than $15 \%$ of their healthcare workforce due to AIDS and, in many other countries, midwives and health workers are living with HIV $[11,14,16]$. It should also be stressed that the HIV/AIDS epidemic worsens the situation of other diseases like cardiovascular diseases, diabe-

Table 10: Estimated and projected impact of HIVIAIDS on mortality indicators in the seven most affected countries in Africa $[19,20]$

\begin{tabular}{|c|c|c|}
\hline & $1995-2000$ & $2010-2015$ \\
\hline \multicolumn{3}{|c|}{ Life expectancy at birth(years) } \\
\hline Without AIDS & 62.3 & 67.0 \\
\hline With AIDS & 50.2 & 37.6 \\
\hline Absolute difference & 12.1 & 29.4 \\
\hline \multicolumn{3}{|c|}{ Number of deaths(millions) } \\
\hline Without AIDS & 3 & 3 \\
\hline With AIDS & 5 & 10 \\
\hline Absolute difference & 2 & 6 \\
\hline \multicolumn{3}{|c|}{ Infant mortality rate(per I 000 ) } \\
\hline Without AIDS & 55.4 & 40.7 \\
\hline With AIDS & 66.1 & 54.6 \\
\hline Absolute difference & 10.2 & 13.9 \\
\hline \multicolumn{3}{|c|}{ Child mortality rate(per I 000 ) } \\
\hline Without AIDS & 80.2 & 56.9 \\
\hline With AIDS & 108.8 & 100.2 \\
\hline Absolute difference & 28.6 & 43.3 \\
\hline
\end{tabular}




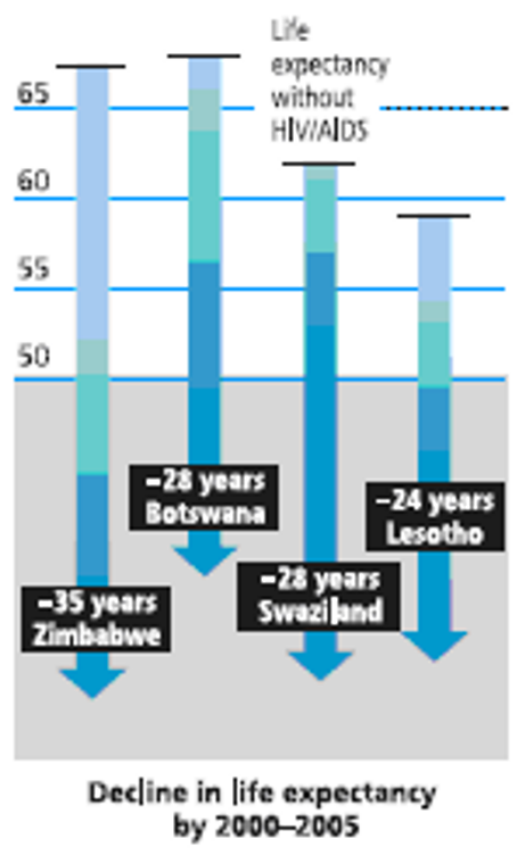

Source: Human Development Report 2003

Figure 3

Loss of life expectancy due to HIVIAIDS in the most affected countries. The most affected countries by HIV/ AIDS have lost tens of years of life expectancy.

tes and tuberculosis. For instance, $80 \%$ of tuberculosis patients are HIV positive in countries with high prevalence of HIV $[19,20]$.

\section{Impact on economic indicators}

Contrary to the majority of diseases, HIV/AIDS kills and disables adults in the most productive part of their lives. Consequently, it is affecting business, investment, industry and agricultural sustainability, and ultimately reducing families' income and economic growth. Although at dif- ferent degrees, all the national reports reviewed stress the negative impact of HIV/AIDS on income at individual, community and national levels [11-18].

At the moment, it is difficult to estimate precisely the real economic impact of HIV/AIDS on the whole African continent. However, many tentative estimates have been made. In 2000, the World Health Organization estimated a yearly reduction of $1 \%$ of the GDP in the most affected African countries. In 2002, UNAIDS gave a much higher estimation of $2.6 \%$. According to the Macroeconomics and Health Commission, in 2001, the cost of HIV/AIDS was between $11.7 \%$ and $35.1 \%$ of the Gross National Product in Africa [19]. For South Africa, the World Bank predicts that in 2010, the GDP would be 17\% lower than it would be without HIV/AIDS [26]. The loss of labour force is indisputable, though it is not directly perceived by employers because it is essentially comprised of non-qualified workers who can easily be replaced from the large reservoir of unemployed. However, according to FAO estimates, by 2020, the projected agricultural labour force would be reduced by at least $10 \%$ in 12 countries and by $20 \%$ or more in five countries (Namibia, Botswana, Zimbabwe, Mozambique and South Africa). By 2020, the loss of general work force is thought to reach $30 \%$ in four countries, 10 to $30 \%$ in 14 countries and $10 \%$ in 16 other countries (Figure 4) [27].

These partial and sometimes controversial estimates, combined with the paucity of national data, indicate the necessity of global interdisciplinary studies that can model, estimate and predict the economic impact of HIV/ AIDS in Africa.

Impact on education and knowledge acquisition

As stressed in the MDGs, education is essential for human development and needs to be enhanced especially in lowand medium-income countries. Unfortunately, HIV/AIDS is reversing the trend towards the achievement of universal primary education in most African countries. In Africa,

Table I I: The Millennium Project [22]

\begin{tabular}{|c|c|}
\hline Millennium Development Goals & UN Millennium Project task forces \\
\hline I. Reduce extreme poverty and hunger by half relative to 1990 & I. Poverty and economic development \\
\hline 2. Achieve universal primary education & 2. Hunger \\
\hline 3. Promote gender equality \& empowerment of women & 3. Education and gender equality \\
\hline 4. Reduce child mortality by two-thirds relative to 1990 & 4. Child and maternal health \\
\hline $\begin{array}{l}\text { 5. Improve maternal health, including reducing maternal mortality by three- } \\
\text { quarters relative to } 1990\end{array}$ & 5. HIVIAIDS, malaria, tuberculosis, and access to essential medicines \\
\hline 6. Prevent spread of HIVIAIDS, malaria, and other diseases & 6. Environmental sustainability \\
\hline 7. Ensure environment sustainability & 7. Water and sanitation \\
\hline \multirow[t]{3}{*}{ 8. Develop a global partnership for development } & 8. Improving the lives of slum dwellers \\
\hline & 9. Trade \\
\hline & 10. Science, technology, and innovation \\
\hline
\end{tabular}




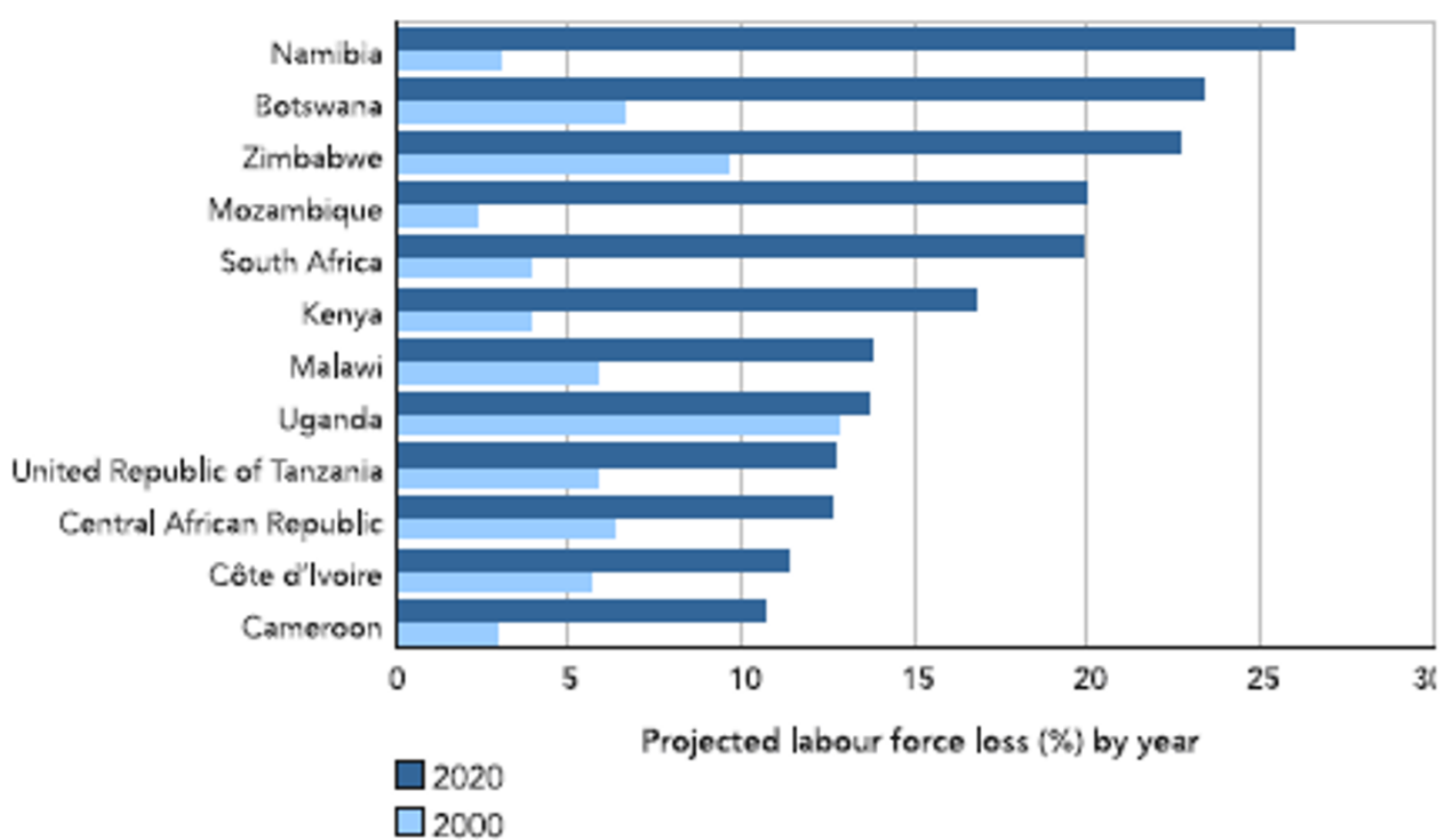

\section{Figure 4}

Reduction in African agriculture labour force due to HIVIAIDS, as estimated in 2000 and projected for 2020 . If the present trend is maintained, by 2020 , HIVIAIDS will have caused more than $25 \%$ reduction in agriculture labour force in some African countries

less than $65 \%$ of children are enrolled in primary school $[28,29]$ and thousands of enrolled children will prematurely leave school under the pressure of HIV/AIDS, including orphans, impoverished and those who withdraw to look after ill members of their families. In Kenya, in 2004, 48\% of all orphans were due to AIDS (Figure 5) [12]. More generally, during the period 1999-2004,

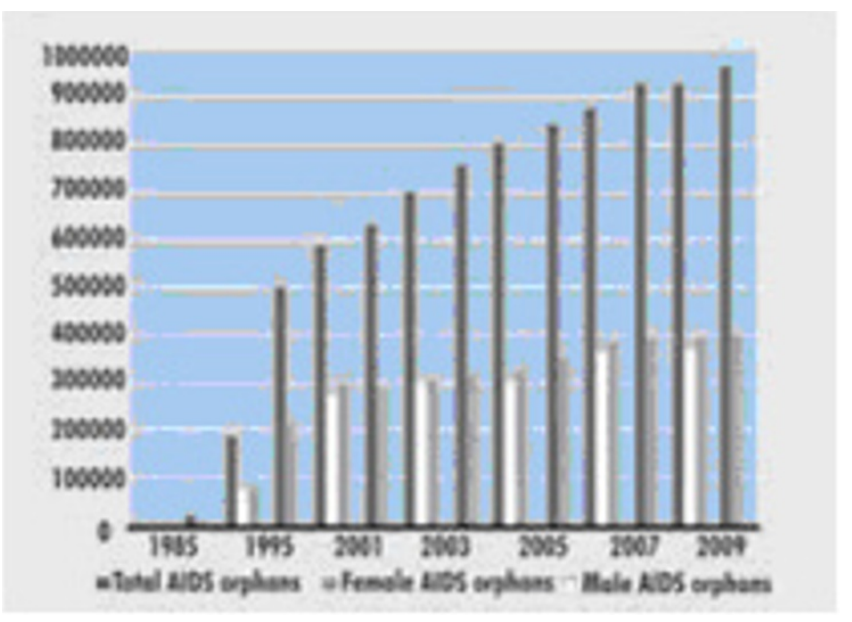

Figure 5

Kenya: Number of orphans by type. Beyond death and disability, a large number of orphans are caused by HIVIAIDS. orphaned children represented $12.3 \%$ of all children under the age of 18 in sub-Saharan Africa and the percentage of child labour reached $31.5 \%, 35.5 \%$ and $41 \%$ in sub-Saharan Africa, Eastern and Southern Africa, and West and Central Africa respectively [22]. The negative impact of HIV/AIDS can partially be evaluated through the impact of orphan-hood on school attendance among 1014 years-olds (Table 12). More globally, the disease is seen to have a threefold impact on education. It affects the cognitive ability of children, the capacity of teachers and the efficiency of staff and managers. For instance, HIV prevalence among South African teachers reaches 21\% among those aged 25-34 and 13\% among those aged 35-44, whereas in the Zambian school system, over $60 \%$ of teacher absence is due to HIV/AIDS (illness, care for ill family members, family funeral, etc.) $[12,15,17,20]$.

\section{Conclusion}

On the basis of the national reports reviewed, it appears clearly that HIV/AIDS is no longer a crisis only for the healthcare sector, but presents a challenge to all sectors [17]. Consequently, HIV/AIDS is a development question and should be viewed as such [12]. The disease is impeding development by imposing a steady decline in the key indicators of human development and hence reversing the social and economic gains that African countries are striving to attain $[11,16]$. Being at the same time a cause 
Table I2: Impact of orphanhood on school attendance among 10-1 4 years-olds (\%)

\begin{tabular}{llllll}
\hline $\begin{array}{l}\text { Percentage } \\
\text { in school }\end{array}$ & West: $\mathbf{9}$ countries & $\begin{array}{l}\text { Central: } \mathbf{6} \\
\text { countries }\end{array}$ & Eastern: 9 countries & Southern: 10 countries & $\begin{array}{l}\text { All: } \mathbf{3 4} \\
\text { countries }\end{array}$ \\
\hline Non-orphan & 67 & 75 & 70 & 88 & 74 \\
Orphan & 58 & 69 & 54 & 84 & 69 \\
Double orphan & 57 & 58 & 49 & 80 & 64 \\
Ratio double vs. non orphan & .86 & .94 & .72 & .90 & .87 \\
\hline
\end{tabular}

Reproduced by kind permission of UNAIDS

and consequence of poverty and underdevelopment, it constitutes a challenge to human security and human development by diminishing the chances of alleviating poverty and hunger, achieving universal primary education, promoting gender equality, reducing child and maternal mortality and ensuring environmental sustainability $[11,13,15,18]$. Shortening human life, eroding people's sense of dignity and self-esteem, causing social exclusion, and traumatising and impoverishing individuals, families and whole communities, HIV/AIDS has the potential to reverse those gains made in human development during the past few years $[14,18]$. With unpredictable implications for economic and social sectors, it is critical that the relationship between HIV/AIDS and human development be acknowledged at all levels and that the principles of sustainable development be a major focus and priority of the African countries' policies and programmes $[12,16]$. The danger and complexity of this disease imposes the necessity of multidisciplinary approaches that model, estimate and predict the real impact of HIV/AIDS on human development of African countries in order to optimise the strategies proposed by individual countries, international institutions and their partners [30].

\section{Limitations of our search}

We are aware of the importance of the topic considered in this paper and the necessity to deal with it seriously and precisely. However, our search relied only on published data by different African countries and international institutions. Consequently, we were limited to data and the numbers available and this may be frustrating not to give a complete panorama of this interesting subject.

\section{Dedication}

This paper is dedicated to African children afflicted by poverty and HIV/AIDS epidemics.

\section{Competing interests}

The author declares that they have no competing interests.

\section{Acknowledgements}

The author is grateful to the Projet de Recherche Global (PGR)
This article has been published as part of BMC Public Health Volume 9 Supplement I, 2009: The OptAIDS project: towards global halting of HIV/AIDS. The full contents of the supplement are available online at http:// www.biomedcentral.com/I47I-2458/9? issue=SI.

\section{References}

I. UNPD: The Human Development Indices. United Nations Development Programme. Human development report office 2004.

2. UNDP: Human Development reports. [http://hdr.undp.org/]. accessed 4/I2/2008

3. Boutayeb A, Serghini M: Heath indicators and human development in the Arab region. International Journal of Health Geographics 2006, 5:61.

4. Boutayeb A: Social Inequalities and health Equity in Morocco. International Journal for Equity in Health 2006, 5: I.

5. The World Health: Global defence against the infectious diseases threat. Geneva, World Health Organization. WHO/CDS/ 2003.15.

6. The World Heralth: Reducing Risk: Promoting Health Life 2002 [http://www.who.int/whr/2002/en/]. Geneva, World Health Organization, Annual Report accessed 4/12/2008

7. The World Health: Today's challenge. 2003 [http://www.who.int/ whr/2003/en]. Geneva, World Health Organization, Annual Report accessed 4//2/2008

8. The World Health: Make every mother and child count. 2005 [http://www.who.int/whr/2005/en/]. Geneva, World Health Organization, Annual Report accessed 4//2/2008

9. Jones G, Steketee RW, Black RE, Bhutta ZA, Morris SS, Bellagio Child Survival Study Group: How many child deaths can we prevent this year? Lancet 2003, 362:159-164.

10. The World Health: Changing history. 2004 [http://www.who.int/ whr/2004/en/]. Geneva, World Health Organization, Annual Report accessed 4/I 2/2008

II. Zambia Human Development Report 2007: Enhancing household capacity to respond to HIV and AIDS. United Nations Development Programme; 2007.

12. Mozambique Human Development Report 2007: Challenges and opportunities: the response to HIVIAIDS. United Nations Development Programme; 2007.

13. Kenya Human Development Report 2006: Human security and human development: a deliberate choice. United Nations Development Programme; 2006.

14. Malawi Human Development Report 2005: Reversing HIVIAIDS in Malawi. United Nations Development Programme; 2005.

15. Rapport sur le Développement Humain au Bénin: " VIHIAIDS" et Développement Humain 2005. United Nations Development Programme; 2005.

16. Zimbabwe Human Development Report 2003: Redirecting our responses to HIV and AIDS. United Nations Development Programme; 2003.

17. South Africa Human Development Report 2003: The challenge of Sustainable Development in South Africa: Unlocking People's Creativity. 2003 [http://hdr.undp.org/en/reports/nationalre ports/africa/southafrica/south afr ica 2003 en.pdf ]. United Nations Development Programme accessed 4/I2/2008

18. Botswana Human Development Report 2000: Towards an AIDSFree generation. United Nations Development Programme; 2005. 
19. United Nations: The impact of AIDS. Geneva, United Nations Department of Economic and Social Affairs/Population Division, World Population Prospects; 2004.

20. UNAIDS: HIVIAIDS estimates. [http://data.unaids.org]. accessed $4 / 12 / 2008$

21. Macroeconomics and Health: Investing in Health for Economic Development. World Health Organization Geneva; 200 I.

22. Sachs JD, McArthur JW: The Millennium Project: a plan for meeting the Millennium Development Goals. Lancet 2005, 365:347-353.

23. UNDP: HIVIAIDS and human Development Thematic Guidance Note. United Nations Development Programme NHR Occasional Paper 4; 2005.

24. Quinn TC: AIDS in Africa: a retrospective. Bulletin of the World Health Organization 200I, 79: II56-II58.

25. Mashelkar RA: Nation Building through Science and Technology: A Developing World Perspective. 10th Zuckerman Lecture. Innovation Strategy Today 2005, I: 16-32.

26. The World Bank: Sustainable development in a dynamic world. The World Bank, Washington, D.C., Development Report; 2003.

27. UNAIDS: The impact of AIDS on people and societies. [http:l /data.unaids.org/pub/GlobalReport/2006/2006 GR CH04 en.pdf]. accessed 4//2/2008

28. UNESCO: Education for All in Least Developed Countries. [http://unesdoc.unesco.org/images/00/4/001472//47259M.pdf]. accessed 4/12/2008

29. UNICEF: The state of the world's children 2006. The United Nations Children's Fund; 2005.

30. Boutayeb A: The double burden of communicable and non communicable diseases in developing countries. Transactions of the Royal Society of Tropical Medicine and Hygiene 2006, 99: I 9 I- 199.

Publish with Biomed Central and every scientist can read your work free of charge

"BioMed Central will be the most significant development for disseminating the results of biomedical research in our lifetime. "

Sir Paul Nurse, Cancer Research UK

Your research papers will be:

- available free of charge to the entire biomedical community

- peer reviewed and published immediately upon acceptance

- cited in PubMed and archived on PubMed Central

- yours - you keep the copyright 